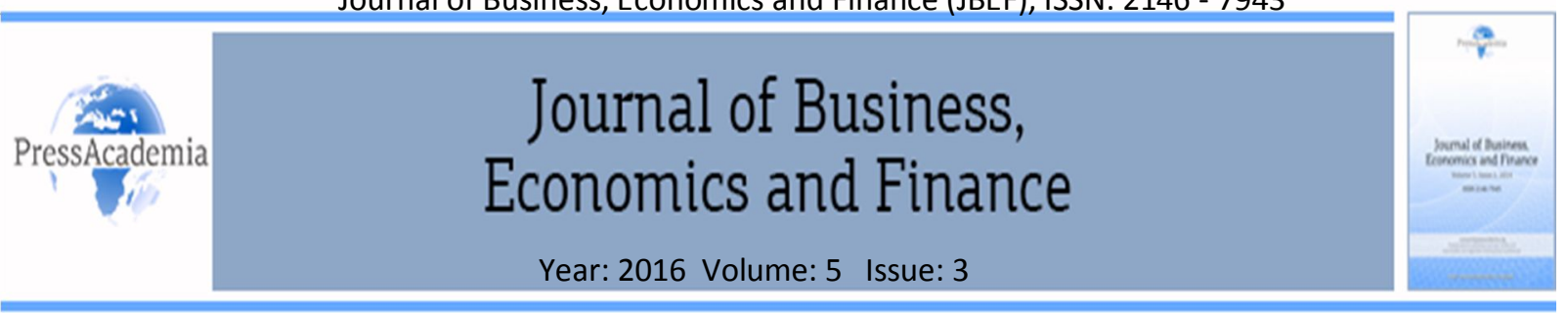

\title{
GENDER EARNINGS GAP IN URBAN PAKISTAN: EVIDENCE FROM ORDINARY LEAST SQUARES AND QUANTILE REGRESSIONS
}

\section{DOI: 10.17261/Pressacademia.2016321972}

\author{
Liaqat $\mathrm{Ali}^{1}$, Dr. Naveed Akhtar ${ }^{2}$ \\ ${ }^{1}$ Hamdard University. liaquat fbs@yahoo.com \\ ${ }^{2}$ National University of Modern Languages.nab_phd@yahoo.com
}

\begin{abstract}
The objective of this paper is to analyze the gender earning gaps existing in urban areas of Pakistan using data from a household survey. The earning functions have been estimated separately for males and females using Ordinary Least Squares (OLS) as well as quantile regressions including education, literacy, experience, employment related variables such as type of industry and occupation and age as explanatory variables. The earning gaps between males and females have also been analyzed using the Blinder-Oaxaca decomposition method. Results suggest higher mean earnings for males as compared to females but higher incremental returns to investment in human capital for females at all levels of education. Further, higher returns to schooling have also been noted in bottom part of the income distribution i.e. $5^{\text {th }} \& 25^{\text {th }}$ quantiles for workers of both sexes as compared to those present in the top of the distribution i.e. $75^{\text {th }} \& 95^{\text {th }}$ quantiles at all educational levels. Education, industry of employment and occupations has been emerged as the main determinants of income gap between male and female workers in urban Pakistan.
\end{abstract}

Keywords: Education, employment, gender earnings gap, quantile regression, Pakistan.

JEL Classification: 126, J16, C21

\section{INTRODUCTION}

Gender equality is treated as a fundamental human right (UNDP, 2014b) and is a necessary foundation for peaceful, prosperous and sustainable world (UN, 2016). It improves the prospects of families, communities and nations and cause improvement in productivity as well as increase in income (UNDP, 2014a). Gender equality is also included in the Sustainable Development Goals (SDGs) to be achieved by 2030 and adopted by the United Nation's member states at the Sustainable Development Summit on September, 2015 (UNDP, 2016). Despite being included in the United Nation's Millennium Development Goals (MDGs), adopted by the world leaders under Millennium Declaration at the turn of the century, as one of the goals (Malhotra, Pande, \& Grown, 2003) and witnessing considerable reductions, gender disparities still exist in number of indicators of education and employment in developing countries (UN, 2014). Moreover, it is also a fact and widely observed consistent phenomenon that women earn less than men (Polachek \& Xiang, 2014) in spite of implementation of antidiscrimination policies and increased participation of women in the labor force as well as acquisition of higher women's capital.

Gender equality has been an interesting area for labor economists as well as for policy makers (Jung, 2014). The earnings of workers have been at the core of empirical research in the field of economics and other social sciences for decades (Montenegro \& Patrinos, 2014). The differences between earnings of male and female workers expressed as percentage of male earning is termed as gender wage gap (Taniguchi \& Tuwo, 2014). In the context of Pakistan, major contributions in the field of gender earnings gap come from but not limited to Ashraf and Ashraf (1993); Nasir (1998); Ashraf (2001); Aslam (2005); Nasir (2005); Siddiqui (2007); Qureshi (2012); and Ali and Akhtar (2014). All of these studies are based on estimation of earning functions through 
conventional method of Ordinary Least Squares (OLS). As OLS regression technique give summary estimates by calculating the average effects of explanatory variables on the dependent variable (Coad \& Rao, 2007) and is based on the mean of the conditional distribution of dependent variable in the regression analysis (Martins \& Pereira, 2004; Wu \& Liu, 2009). A more complete picture can be obtained by computing several regression curves matching to different percentage points of each distribution through quantile regressions (Cade \& Noon, 2003; Coad \& Rao, 2007; Pham \& Reilly, 2007). The results of quantile regression (QR) are typically robust even for skewed distributions containing outliers in the response variables (Coad \& Rao, 2007; Pham \& Reilly, 2007) and are considered a standard analytical tool in the income and wage studies (Yu, Lu, \& Stander, 2003). The current study is different from the earlier ones in number of ways. First, it is based on data for urban paid employees only and second, earning functions have been estimated by applying QR in addition to OLS. Third, gender earning gaps have been decomposed using Oxaca-Blinder decompostion method.

We have analyzed gender differences in income through Mincerian earning functions across various levels of education, experience, industry of employment, occupation and age for full-time paid employees residing in urban areas of Pakistan. In the context of Pakistan's labor market, the need of fresh study on gender earning gap arises on account of adverse law and order situation, increase in rate of inflation, growing energy crises tied with decreasing growth rate of economy. We have found higher mean earnings for males as compared to females but higher incremental returns to investment in human capital for females as compared to males at all levels of education. Our finding of higher incremental returns to education for females in comparison to males is in line with previous research done in Pakistan that includes Ashraf \& Ashraf (1993), Nasir (1998), Ashraf (2001), Nasir (2005), Aslam (2005), Ali (2007), Siddiqui (2007), Qureshi (2012) and Ali \& Akhtar (2014). While most of the previous studies on gender earnings differential in Pakistan are based on OLS, we have also estimated earning functions using QR.

According to results of $Q R$, higher returns to schooling have been noted in bottom part of the income distribution i.e. $5^{\text {th }} \& 25^{\text {th }}$ quantiles both for men and women as compared to those present in the top of the distribution i.e. $75^{\text {th }} \& 95^{\text {th }}$ quantiles at all educational levels. Further, we have also found education, industry of employment and occupations as the main determinants of income gap between male and female workers in urban Pakistan. The rest of the paper is organized as follows. Some stylized facts in Pakistan's labor market are presented in the section II. Theoretical framework and data are discussed in section III whereas empirical results and findings are discussed in the section IV. Finally section $\mathrm{V}$ concludes the paper.

\section{GENDER ISSUES IN PAKISTAN'S LABOR MARKET}

Like other developing countries, substantial imbalances also exist in Pakistan's labor market and can be found in various socio-economic aspects such as labor force participation rate, employment and unemployment, enrolment and literacy rates, life expectancy and most importantly income of the male and female workers. Figure 1 shows the recent trend in gender wage gaps in terms of average monthly income of employees in Pakistan and its rural and urban areas from 2004-05 to 2014-15. The substantial differences in gender wage gap in urban and rural areas of Pakistan can be noticed. The downward trend in gender wage gap in urban areas is also visible. 
Figure 1: Average Monthly Income of Female Employees as \% Age of Males

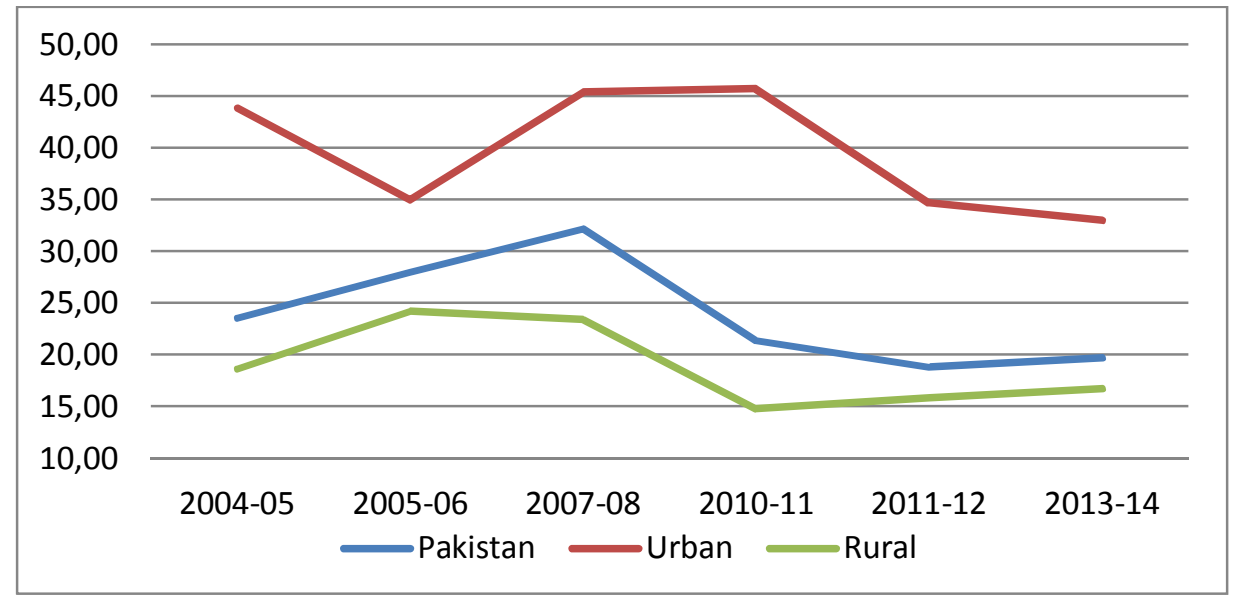

Source: Authors' calculations based on HIES (Various issues)

\subsection{Educational Attainment}

Investment in education is believed to bring justice, prosperity and opportunity (Brown, 2003) and improvement in social status (Bauer, Feng, Riley, \& Xiaohua, 1992). Educational credentials are also considered to have strong bond with good jobs (Bauer, et al., 1992; Brown, 2003), higher rewards (Brown, 2003) and improved occupational status (Bauer, et al., 1992). In the words of Brown (2003) "Credentials are the currency of opportunity".

According to Sarwar, et al., (2013) human capital formation is the only way to reverse the negative impacts of growing population for a developing country like Pakistan because it directly improve earning ability of the poor (Son, 2010; Yamauchi, 2010). Human capital is also a fundamental factor for the improvement of living standards of people in a country (Dougherty \& Herd, 2008). But, a fundamental challenge in fostering human capital formation lies in promoting the educational capital (Guichard \& Larre, 2006). Education being the most important element of human capital is two ways process (Afzal, Malik, Begum, Sarwar, \& Fatima, 2011) which faster economic growth (Jehan, 2000) and productivity on one side and reduces poverty on the other side (Afzal, et al., 2011; Montenegro \& Patrinos, 2014).

In Pakistan, the gender differences between males and females exist in educational attainment. For example, literacy rate for males was $71 \%$ as compared to $48 \%$ for females during 2012-13 (Finance, 2014). Similarly, gross enrolment rate was $98 \%$ for males as compared to $83 \%$ for females whereas as net enrolment rate was $61 \%$ males and $54 \%$ for females (Finance, 2014).

Development of education was also included in the MDG's adopted by the UN. Pakistan had to achieve $100 \%$ primary education and 88\% literacy rate by 2015 with gender parity index (GPI) equal to one. However, Pakistan has missed the MDG's goals as the overall literacy rate was just $58 \%$ against the target of $88 \%$ during 2013-14. Further, gender disparity in terms of literacy also exist in Pakistan which is clear from the fact that $47 \%$ of female were literate against $70 \%$ of males (Pakistan Economic Survey, 2014-15). Pakistan could not achieve the goals set in the MDGs due to lack of sustained leadership, economic instability, political turmoil, insecurity and recurrent natural disasters (UNDP, 2015). Albeit having witnessed considerable improvement if compared with baseline scenario in 1990-91, gender disparities still prevail not only in primary and secondary education but also in literacy in Pakistan (Figure 2). 
Figure 2: Pakistan's Educational Achievements towards MDG's Targets

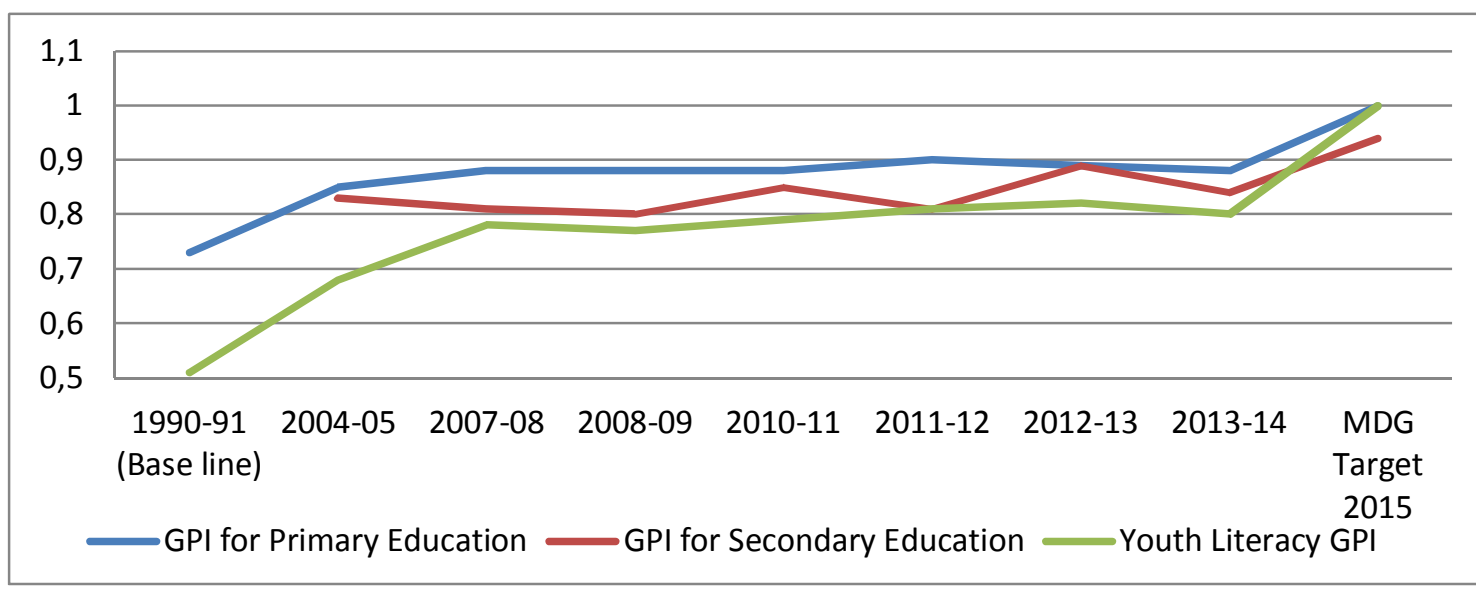

Source: Authors Elaborations upon data from PSLM 2013-14

\subsection{Population and Employment}

Currently, Pakistan is the $6^{\text {th }}$ most populous country of the world (Sarwar, Fakher, Ali, \& Mudassar, 2013) with total estimated population of 191.7 million in 2015 out of which $48.3 \%$ were females (MOF, 2014). Whereas composition of population by sex has remained stagnant since last housing and population census in1998, the trend of growing urbanization is evident from the fact that proportion of urban population has increased from $32.5 \%$ in 1998 to 38\% in 2013 (PBS, 2014). In the current study, we have restricted our analysis to a sample from urban areas of Pakistan in contrast to most of the previous studies which analysis both urban and rural areas.

Figure 3: Age Specific Activity Rate by Sex for Pakistan

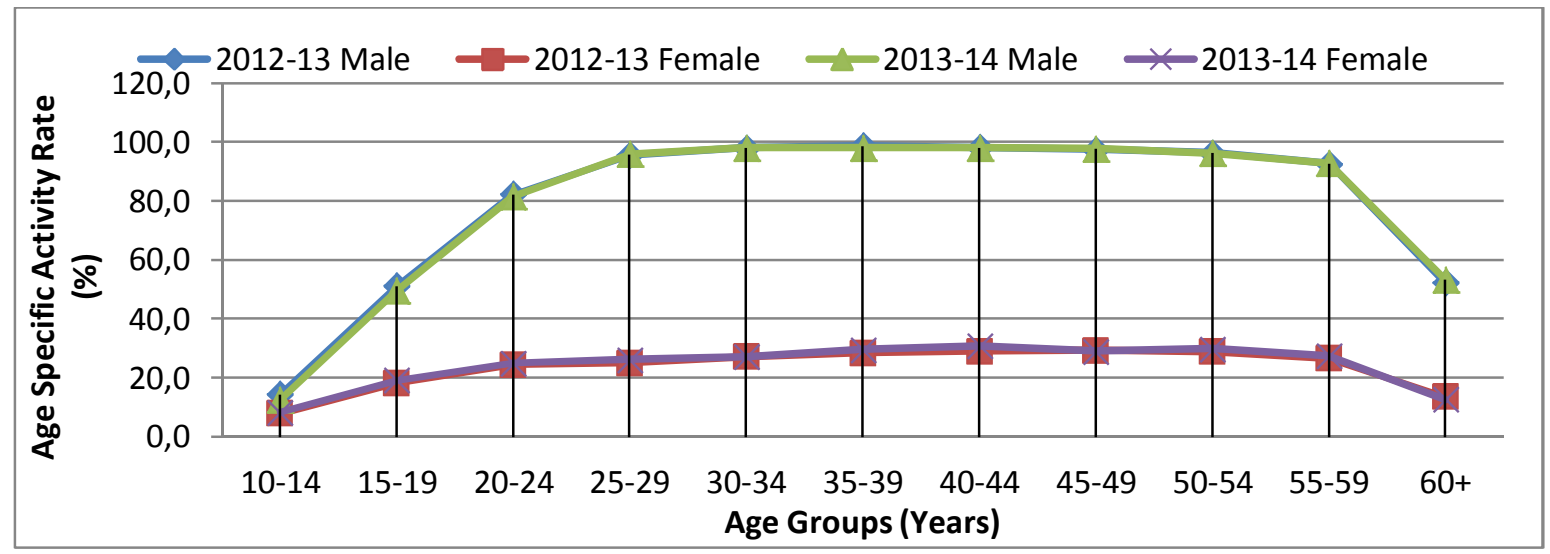

Source: Compendium of Gender Statistics of Pakistan, 2014

According to Labor Force Survey (2012-13), the total civilian labor force in Pakistan was $45.69 \%$ of the total population comprising $35.08 \%$ of male and $10.60 \%$ of female. The labor force participation rates for males and females were $68.70 \%$ and $21.67 \%$ in $2012-13$ respectively. The significant gender gaps exist in Pakistan in terms of labor force participation rates as is evident from figure 3. The participation of females in the labor force is drastically low as compared to their male counterpart across all age groups in Pakistan (Figure 3).

At global level, vulnerable employment rates, which is defined as proportion of contributing family workers and own account worker, are higher for women than for men. In developing regions, 60 per cent of women were in vulnerable employment in 2013, compared to 54 per cent of men (UN, 2014). In Pakistan, more than half of the female workers i.e. $55 \%$ were engaged as contributing family workers in contrast to $15 \%$ of males. Gender 
differences also exist in the sector of employment and occupations. Females are generally engaged in low paid informal jobs in agriculture sector. For example, $75 \%, 11 \%$ and $14 \%$ of the employed women were engaged in the agriculture, industry and services sectors against $33 \%, 26 \%$ and $41 \%$ of males during 2012-13 in Pakistan respectively (PBS, 2014a). Like other researchers e.g. Ashraf \& Ashraf (1993); Blau \& Kahn (1992); Gornick \& Jacobs (1998); Harkness (1996); Nasir (1998); Rice, (1999); Su \& Heshmati (2013) and Taniguchi \& Tuwo (2014), we have also used employment related characteristics like industry and occupation as explanatory variables in our estimated earning functions through dummy variables.

\section{DATA AND METHODOLOGY}

The returns to human capital and gender earning gaps can be estimated by following Mincerian approach as baseline framework (Pastore, Sattar, \& Tiongson, 2013). According to Montenegro \& Patrinos (2014), Mincerian model produce more stable results than one can expect. The basic earning function used in the current study in modified form can be written as under:-

$\ln w_{i}=\alpha+\beta_{1} S_{i}+\beta_{2} X_{i}+\beta_{3} X_{i}^{2}+\sum_{j=1}^{n} \delta Z_{i j}+u_{i}$

where $w_{i}$ is natural log of the monthly income for an $i^{\text {th }}$ individual. Dependent variable has been used in logtransformation form in order to correct for possible skew and heteroscedasticity (Vassil, Eamets, \& Mõtsmees, 2014). $S_{i}$ stands for the years of schooling, $X_{i}$ is labor market experience of an individual in completed years. $X_{i}^{2}$ is the squared term of experience which has been included in the earning function in order to capture nonlinearity in the earnings of individual throughout their life span (Pastore, et al., 2013; Willis, 1986). $Z_{i j}$ is a vector of variables such as literacy, industry, occupation and age of individuals and $u_{i}$ is error term representing other variables, not measured and assumed to be independent of the other explanatory variables.

The earning functions can also be used to estimate the returns to different levels of schooling by using the education dummies for each level (Montenegro \& Patrinos, 2014). Keeping in view the education system of Pakistan five dummy variables for primary $\left(D_{p}\right)$, middle $\left(D_{m}\right)$, secondary $\left(D_{s}\right)$, higher secondary $\left(D_{h s}\right)$ and tertiary $\left(D_{t}\right)$ levels have been defined. These dummy variables denote the fact that a person concerned has achieved that specific level of education (Montenegro \& Patrinos, 2014). The dummy variable for individuals without formal schooling has been used as an omitted category and has not been included in the model in order to avoid the problem of singularity in the matrix. The extended model including these dummy variables takes the following form:-

$\ln w_{i}=\alpha+\beta_{p} D_{p i}+\beta_{m} D_{m i}+\beta_{s} D_{s i}+\beta_{h s} D_{h s i}+\beta_{t} D_{t i}+\beta_{1} X_{i}+\beta_{3} X_{i}^{2}+\sum_{j=1}^{n} \delta Z_{i j}+u_{i}$

OLS regression technique, presented in equation (1) and (2), give summary estimates by calculating the average effects of explanatory variables on the dependent variable (Coad \& Rao, 2007) and is based on the mean of the conditional distribution of dependent variable in the regression analysis (Martins \& Pereira, 2004; Wu \& Liu, 2009). A more complete picture can be obtained by computing several regression curves matching to different percentage points of each distribution through quantile regressions (Cade \& Noon, 2003; Coad \& Rao, 2007; Pham \& Reilly, 2007). QR has another advantage over OLS because it makes possible to obtain a complete conditional distribution of $Y$ variable instead of focusing only on means as is the case in OLS (Fattouh, Scaramozzino, \& Harris, 2001) and is considered a standard analytical tool in the income and wage studies (Yu, et al., 2003).

The QR was first introduced by Koenker and Bassett in 1978 (Coad \& Rao, 2007; Koenker \& Hallock, 2001) and keeping in view the setting of wage equation (see Martins \& Pereira, 2004; McGuinness \& Doyle, 2004) can be written as under:-

$\operatorname{lnw}_{i}=x_{i} \beta_{\theta}+u_{\theta i}$ withQuant $_{\theta}\left(\ln _{i} \mid x_{i}\right)=x_{i} \beta_{\theta}$

where $x_{i}$ and $\beta_{\theta}$ denote the vectors of exogenous variables and parameters respectively. Quant ${ }_{\theta}\left(\operatorname{lnw}_{i} \mid x_{i}\right)$ is the $\theta^{\text {th }}$ conditional quantile of In w given $x$. According to Matins \& Pereira (2004), the $\theta^{\text {th }}$ quantile, which lies between ' 0 ' and ' 1 ', can be defined as under:- 
$\min _{\beta \in R^{k}}\left\{\sum_{i: \ln w_{i} \geq x_{i} \beta} \theta\left|\ln w_{i}-x_{i} \beta_{\theta}\right|+\sum_{i: \ln w_{i} \geq x_{i} \beta}(1-\theta)\left|\ln w_{i}-x_{i} \beta_{\theta}\right|\right\}$

The above equation can be written as:

$\min _{\beta \in R^{k}} \sum_{i} \rho_{\theta}\left(\ln w_{i}-x_{i} \beta_{\theta}\right)$

where $\rho_{\theta}(\varepsilon)$ is defined as check function which is written as $\rho_{\theta}(\varepsilon)=\theta \epsilon$ if $\varepsilon \geq 0$ or $\rho_{\theta}(\varepsilon)=(\theta-1) \epsilon$ if $\varepsilon<0$. This problem can be solved through method of linear programming. The least absolute deviation (LAD) is the most common form of quantile regression (Melly, 2002) and estimator of $\boldsymbol{\beta}$ can be obtained by setting $\theta=0.5$. The various quantiles can be obtained by setting the various values of $\theta$. For example, first and third quartiles can be obtained by setting the values of $\theta$ equal to 0.25 and 0.75 respectively.

After fitting the regression model given in the equation (1) through equation (5), the private return to different levels of education can be obtained as under:-

$r_{p}=\left(\beta_{p}\right) /\left(S_{p}\right)$

$r_{m}=\left(\beta_{m}-\beta_{p}\right) /\left(S_{m}-S_{p}\right)$

$r_{s}=\left(\beta_{s}-\beta_{m}\right) /\left(S_{s}-S_{m}\right)$

$r_{h s}=\left(\beta_{h s}-\beta_{s}\right) /\left(S_{h s}-S_{s}\right)$

$r_{t}=\left(\beta_{t}-\beta_{h s}\right) /\left(S_{t}-S_{h s}\right)$

where $\mathrm{S}_{\mathrm{p}}, \mathrm{S}_{\mathrm{m}}, \mathrm{S}_{\mathrm{s}}, \mathrm{S}_{\mathrm{hs}}$ and $\mathrm{S}_{\mathrm{t}}$ are years required to complete primary, middle, secondary, higher secondary and tertiary education.

Analysis of the decomposition of earnings gap between male and female workers is another objective of this paper. According to Oaxaca \& Blinder (1973) decomposition method, also followed by Su \& Heshmati (2013) and Taniguchi \& Tuwo (2014), the gap in income is divided into two parts. The observable differences in productive characteristics of individuals generate the first part of the income gap whereas the remaining gap is due to differences in the returns to individual level attributes (Boraas \& Rodgers, 2003; Jung, 2014; Pham \& Reilly, 2007; Su \& Heshmati, 2013; Taniguchi \& Tuwo, 2014; Weichselbaumer \& Winter-Ebmer, 2003).

Specifically, the overall gap in income between male and female workers is equal to:

$\mathrm{D}=\frac{\mathrm{INC}_{\mathrm{m}}}{\mathrm{INC}_{\mathrm{f}}}-1$

where, $\mathrm{INC}_{\mathrm{m}} / \mathrm{INC}_{\mathrm{f}}$ is the ratio of male to female income. Logarithm of equation (2) along with combination of estimated result in equation (1) yields the overall male-female gap in income as under:

$\ln \mathrm{D}=\ln \overline{\mathrm{INC}}_{\mathrm{m}}-\ln \overline{\mathrm{INC}}_{\mathrm{f}}=\overline{\mathrm{X}}_{\mathrm{m}} \widehat{\beta}_{\mathrm{m}}-\overline{\mathrm{X}}_{\mathrm{f}} \hat{\mathrm{f}}_{\mathrm{f}}$

where $\ln \overline{\mathrm{INC}}_{\mathrm{m}}$ and $\ln \overline{\mathrm{INC}}_{\mathrm{f}}$ represent average values of log yearly income of males and females respectively. $\bar{X}_{m}$ and $\bar{X}_{\mathrm{f}}$ represent average values of productive attributes of the males and females. $\hat{\beta}_{\mathrm{m}}$ and $\widehat{\beta}_{\mathrm{f}}$ stands for vectors of estimated coefficients obtained from separate regressions for males and females.

Following Su \& Heshmati (2013) and Oaxaca (1973) the equation (3) can be expressed for purpose of decomposition as under:

$\ln \mathrm{D}=\left(\overline{\mathrm{X}}_{\mathrm{m}}-\overline{\mathrm{X}}_{\mathrm{f}}\right)\left[\Omega \widehat{\beta}_{\mathrm{m}}+(\mathrm{I}-\Omega) \widehat{\beta}_{\mathrm{f}}\right]+\left[\overline{\mathrm{X}}_{\mathrm{m}}(\mathrm{I}-\Omega)+\overline{\mathrm{X}}_{\mathrm{f}} \Omega\right]\left(\widehat{\beta}_{\mathrm{m}}-\widehat{\beta}_{\mathrm{f}}\right)$

where, I stand for an identity matrix and $\Omega$ stands for sloping matrix of weights. Both explained and unexplained variations in the earnings differentials are explained by the Blinder-Oaxaca decomposition method (Chzhen \& Mumford, 2010; Jung, 2014; Kingdon, 2001; Taniguchi \& Tuwo, 2014; Weichselbaumer \& WinterEbmer, 2003).

The current study is based on the individual level data obtained from a household survey known as PSLM conducted by Pakistan Bureau of Statistics (PBS) in 2010-11. Under PSLM; two types of surveys at district and 
provincial levels are conducted whereas each survey is repeated in the alternate year. The district level surveys covers only social indicators, the provincial level surveys also known as Household Integrated Economic Survey (HIES), provide information on number of social and economic indicators like demographics, enrolment rates, literacy, employment, household size, income and consumption, savings etc.(PBS, 2014b). The current study uses the data from HIES which was obtained from 16341 households during July, 2010 to June 2011 (PBS, 2011).

The demographic section of 2010-11 survey provides information about 109181 individuals comprising $51 \%$ of male and $49 \%$ of female. However, keeping in view the requirements of the study, only the data relating to urban and paid employees was used and our final sample was reduced to 7842 individuals out of which 6828 (87\%) were males and 1014 (13\%) were females.

The main variable of interest in our study is monthly earnings, which has been used as a dependent variable in the earning equation. For comparison purpose only those workers have been included in analysis who reports their incomes on monthly basis from their major and primary occupations. Two measures of literacy skills i.e. reading \& writing and numeracy, have also been used as categorical variables denoting the value of " 1 " if a person holds the skill and " 0 " otherwise. HIES provide information on completed years of schooling which has been directly used in the estimation of earning functions in equation (1) as well as for defining the five different dummy variables, which have been used as explanatory variables in the estimation of equation (2). The information on labor market experience at individual level was not available in the survey and has been derived by deducting completed years of schooling less six from age by following the literature ( e.g Ali, 2007; Grajek, 2001; Montenegro \& Patrinos, 2014 and Willis, 1986). Type of industry, nature of occupation and age has also been included in the earning function by defining different categorical variables. Operational definitions of variables are presented in table 1.

Table 1: Operational Definitions of Variables

\begin{tabular}{|l|l|}
\hline Name of Variables & Description \\
\hline In_y & Logarithm of the monthly income earned from major employment \\
S & Completed years of schooling \\
Edu0 & Without formal education; Reference group \\
Edu1 & 5 or less years of schooling \\
Edu2 & 8 or less but greater than 5 years of schooling \\
Edu3 & 9 or 10 years of schooling (secondary) \\
Edu4 & 11 or 12 years of schooling (higher secondary/college) \\
Edu5 & $\begin{array}{l}13 \text { or more years of schooling graduates, masters and professional } \\
\text { degrees (university education) }\end{array}$ \\
Literacy & \\
Lit1 & Reading and writing ability (Reference group) \\
Lit2 & No ability to read and write \\
Ability to solve simple arithmetic questions (Reference group) & No ability to solve simple arithmetic questions \\
Experience & Experience in years calculated as age - completed years of \\
Exp. & schooling -6 \\
Exp_Sq & Exp. ${ }^{*}$ Exp. \\
Industry & Agriculture, hunting, forestry, logging and Fishing \\
Ind1 & Mining and Manufacturing \\
Ind2 & Electricity, and gas \\
Ind3 & Construction \\
Ind4 & Trade \& restaurants and hotels (Reference group) \\
Ind5 & Transport, storage and communication \\
Ind6 &
\end{tabular}




\begin{tabular}{|l|l|} 
Ind7 & Financing, insurance, real estate and other services \\
Occupation & Senior professionals and managers \\
Occu1 & Technicians and associate professionals \\
Occu3 & Clerks, service \& sales workers (reference group) \\
Occu4 & Skilled fishery \& agricultural workers \\
Occu5 & Trade \& craft workers \\
Occu6 & Assemblers, plant \& machine operators \\
Occu7 & Other elementary occupations \\
Age: & Age in completed years \\
age1 & Under 20 \\
age2 & $20-29$ \\
age3 & $30-39$ \\
age4 & $40-49$ \\
age5 & $50-59$ \\
age6 & 60 \& Above \\
\hline
\end{tabular}

\section{FINDINGS AND DISCUSSIONS}

The average monthly earnings of male and female paid employees in urban areas along with mean earning gap are presented in table 2 . In the overall sample, male and female monthly earnings stand at Rs.10807 and Rs.7702 showing a gap of Rs.3105. Female earnings stand at $71 \%$ of the male earnings and this finding corroborates the observations of Polachek \& Xiang, (2014) and Blau \& Kahn, (2007) that female earn consistently less than men on average. Monthly earnings of females having reading \& writing skills (Lit1) are $84 \%$ of male's earnings as compared to $41 \%$ for those without these skills (Table 2). Females without having ability to solve simple arithmetic (lit2) earn $44 \%$ of male earnings whereas those having these skills earn $73 \%$ of male's earnings. The wider gender wage gap in earnings exist for women without education (60\%) or having lower levels of education such as primary (Edu1) (64\%), middle (Edu2) (50\%) and secondary (Edu3) (34\%). The lowest wage gap between male and female workers i.e. 33\% exist when females have tertiary education (Edu5) (Table 2).

Table 2: Average Monthly Earnings of Paid Employees in Urban Areas by Gender (Rupees)

\begin{tabular}{l|l|c|c|c|c}
\hline \multicolumn{2}{c|}{ Variables } & Male (M) & Female (F) & Gap (M-F) & F/M \\
\hline Overall & & 10807 & 7702 & 3105 & 0.71 \\
Lit1 & No & 6743 & 2737 & 4006 & 0.41 \\
Lit2 & Yes & 12245 & 10319 & 1926 & 0.84 \\
Levels of & No & 7039 & 3095 & 3944 & 0.44 \\
Education & Yes & 11158 & 8178 & 2980 & 0.73 \\
& Edu0 & 6833 & 2722 & 4111 & 0.40 \\
& & & & & \\
& Edu1 & 6845 & 2492 & 4353 & 0.36 \\
& Edu2 & 7550 & 3808 & 3742 & 0.50 \\
Type of & Edu3 & 9641 & 6396 & 3245 & 0.66 \\
industry & Edu4 & 12421 & 7017 & 5404 & 0.56 \\
& Edu5 & 23459 & 15685 & 7774 & 0.67 \\
& Ind1 & 8863 & 5693 & 3170 & 0.64 \\
& Ind2 & 9461 & 2997 & 6464 & 0.32 \\
& Ind3 & 15585 & 2860 & 12725 & 0.18 \\
& Ind4 & 7452 & 4900 & 2552 & 0.66 \\
& Ind5 & 7280 & 3765 & 3515 & 0.52 \\
& Ind6 & 10579 & 8812 & 1767 & 0.82 \\
& Ind7 & 14336 & 8640 & 5696 & 0.60
\end{tabular}




\begin{tabular}{|c|c|c|c|c|c|}
\hline \multirow[t]{7}{*}{ Occupation } & Occu1 & 26179 & 13828 & 12351 & 0.53 \\
\hline & Occu2 & 17833 & 10520 & 7313 & 0.59 \\
\hline & Occu3 & 10389 & 4997 & 5392 & 0.48 \\
\hline & Occu4 & 8456 & 1725 & 6731 & 0.20 \\
\hline & Occu5 & 7944 & 2438 & 5506 & 0.31 \\
\hline & Occu6 & 8944 & 4375 & 4569 & 0.49 \\
\hline & Occu7 & 6831 & 3231 & 3600 & 0.47 \\
\hline \multirow[t]{7}{*}{ Age } & Under 20 & 4217 & 2565 & 1652 & 0.61 \\
\hline & $20-29$ & 7589 & 6436 & 1153 & 0.85 \\
\hline & $30-39$ & 11986 & 7725 & 4261 & 0.64 \\
\hline & $40-49$ & 14641 & 10861 & 3780 & 0.74 \\
\hline & $50-59$ & 16637 & 11502 & 5135 & 0.69 \\
\hline & $60 \&$ & 10180 & 4168 & 6012 & 0.41 \\
\hline & Above & & & & \\
\hline \multirow[t]{4}{*}{ Marital status } & Unmarried & 6492 & 6067 & 425 & 0.93 \\
\hline & Married & 13119 & 9114 & 4005 & 0.69 \\
\hline & Widow & 9957 & 7575 & 2382 & 0.76 \\
\hline & Divorced & 6027 & 4691 & 1336 & 0.78 \\
\hline
\end{tabular}

The monthly earnings of female paid employees belonging to urban areas as percentage of male's earning in various industries such as Ind1, Ind2, Ind3, Ind4, Ind5 (see table 1) were 64\%, 32\%, 18\%, 66\% and 52\% respectively (Table 2 ). The highest mean wage gap between male and female worker was found in Ind 3 and lowest in Ind6. Among occupations, the highest wage gap between male and female paid employees i.e. $80 \%$ was found in Occu4 (see table 1) because agriculture is traditionally a mail dominant occupation while the lowest i.e. $41 \%$ was found in Occu2. The difference in monthly earnings between male and female employees in the age group between $20-29$ years was lowest i.e. $15 \%$ and was highest i.e. $59 \%$ for those in the upper age group of 60 years \& above. Further, the mean difference in monthly income between unmarried men and women was only $7 \%$ for paid employees belonging to urban areas of Pakistan as against the $31 \%$ for those who are married (Table 2).

Table 3: Average of Variables

\begin{tabular}{l|c|c|c}
\hline Variables & Both Sexes & Males & Females \\
\hline In_y & 8.92 & 9.006 & 8.34 \\
S & 7.39 & 7.86 & 7.32 \\
Lit1 & 0.728 & 0.739 & 0.655 \\
Lit2 & 0.914 & 0.915 & 0.906 \\
Edu1 & 0.139 & 0.149 & 0.067 \\
Edu2 & 0.119 & 0.127 & 0.064 \\
Edu3 & 0.192 & 0.204 & 0.109 \\
Edu4 & 0.098 & 0.102 & 0.097 \\
Edu5 & 0.186 & 0.316 & 0.166 \\
Exp & 20.972 & 21.192 & 19.493 \\
Exp_Sq & 630.25 & 635.59 & 594.28 \\
Ind1 & 0.028 & 0.028 & 0.029 \\
Ind2 & 0.164 & 0.169 & 0.129 \\
Ind3 & 0.023 & 0.026 & 0.005 \\
Ind4 & 0.132 & 0.15 & 0.01 \\
Ind6 & 0.092 & 0.103 & 0.017 \\
Ind7 & 0.416 & 0.36 & 0.791 \\
Occu1 & 0.131 & 0.102 & 0.325 \\
Occu2 & 0.08 & 0.074 & 0.122
\end{tabular}




\begin{tabular}{l|c|c|c} 
Occu4 & 0.007 & 0.007 & 0.004 \\
Occu5 & 0.142 & 0.142 & 0.14 \\
Occu6 & 0.082 & 0.093 & 0.008 \\
Occu7 & 0.34 & 0.352 & 0.26 \\
Age1 & 0.104 & 0.105 & 0.096 \\
Age2 & 0.319 & 0.314 & 0.353 \\
Age3 & 0.224 & 0.223 & 0.231 \\
Age4 & 0.199 & 0.2 & 0.196 \\
Age5 & 0.118 & 0.12 & 0.103 \\
Age6 & 0.036 & 0.038 & 0.022 \\
Valid N & 7842 & 6828 & 1014 \\
\hline
\end{tabular}

Source: Authors calculations based on data from HIES 2010-11

The averages of variables used in the study are presented separately for males and females in Table 3 . The standard deviations of the variables by the same categories have not been presented in the table in order to save the space and same are available with the authors. The difference in log-monthly income, the response variable in our model, between male and female workers was 0.666 . Although, gender gap in primary and secondary education has considerably reduced during recent decades but still prevails in poor countries (Bertocchi \& Bozzano, 2014). The same is true in case of our sample where the difference in average years of schooling between males and females stands at 0.540 (Table 3). According to Aslam (2005), the gender gap in education in Pakistan exists due to difference in labor market returns to education. The current study focuses on education as the main determinant of income because education is an important and popular policy levers in many countries (Emran \& Shilpi, 2014). Women also lag behind than men in both measure of literacy i.e. lit1 \& lit2 as well as across various levels of education from edu1 through edu5 (Table 3). According to Blau and Kahn, (2007) and Vassil, et al., (2014), women usually have less labor market experience as compared to men following the traditional division in the labor market and family considerations. The same is true in case of our sample where women having mean experience of 19.5 years fall short of men having average experience of 21.2 years (Table 3). As far as industry of the employment is concerned, majority of both men and women i.e. $36 \%$ and $79 \%$ were engaged in Ind 7 followed by $17 \%$ and $13 \%$ in Ind 2 (Table 3 ). The lowest proportion of urban workers of males and females were employed in Ind3 and Ind1 (Table 3).

Gender differences in occupation are expected due to labor market preferences of females who prefer to choose that occupation requiring less on the job training (Blau \& Kahn, 2007). In our sample, highest proportions of males i.e. $35 \%$ and females i.e. $26 \%$ were engaged in Occu 7 followed by $14 \%$ in Occu5. The lowest numbers of males and females workers in urban areas were engaged Occu4 (Table 3). Majority of both men and women employees i.e. $31 \%$ and $35 \%$ were in the age group $20-29$ years (Age2) followed by $22 \%$ and $23 \%$ in Age3 respectively. The lowest proportions of employees of either sex were found in Age6 (Table 3).

The practice of estimation of rates of returns to investment in education is continuing since the late 1950s and estimates of the returns to schooling and to potential experience are a useful indicator of an individual's productivity (Montenegro \& Patrinos, 2014). In a model with log-transformed response variables, like equation (1), the estimated parameters are interpreted as a percent change on wage when independent variable increases by one unit (Vassil, et al., 2014) and $\beta_{1}$ in the wage equation can be viewed as the average rate of return to years of schooling to wage employment (Montenegro \& Patrinos, 2014; Willis, 1986). The size of private returns to education is of great significance because it is the price an individual investor of education receives on his/her own investment (Psacharopoulos, 1985) and also explains personal income distribution (Psacharopoulos, 1985; Willis, 1986). The earning functions estimated separately for males and females through OLS method both for completed years of schooling as well as education dummies are presented in table 4. Education has been used as an explanatory variable in two distinct ways i.e. i) as completed years of schooling and ii) as education dummies representing different levels of education while treating no formal education as a reference category.

The average rates of returns to extra year of schooling in urban areas were $8.6 \%$ for males and $20.7 \%$ for females and were significant at $1 \%$ level (Table 4). The higher rate of return to schooling for females as 
compared to males in all specifications of estimated earning functions have been found in our study which confirms the finding of other studies e.g. Ashraf \& Ashraf (1993); Aslam (2005); Montenegro \& Patrinos (2014) and Siddiqui \& Siddiqui (1998). All education levels have been emerged as significant and positive determinants of income except for edu1 for males and edu1 \& edu2 for females. Further, variation in estimated parameters is more for women which range from 0.07 to 1.86 than for men which range from -0.02 to 0.89 (Table 4). Lit1 is significant in all estimated specification except for females in education dummies whereas lit2 is significant for women but not for men. The average returns to extra year of experience which are significant for both males and females but are higher for females $(9.2 \%$ \& $7.3 \%)$ as compared to men $(5.7 \%$ \& $5.3 \%)$ in both specifications education years and education dummies. The coefficient of experience square is negative in the earning functions for both males and females (Table 4), which exhibits concavity of the earning functions and decreasing returns to the investment in human capital (Pastore, et al., 2013).

All industries of employment have been emerged as significant determinants of earnings of male workers but for females only two industries i.e. Ind3 \& Ind6 are significant in OLS equations. Similarly, Occu2 \& Occu7 are significant determinant of income for both males and females but Occu4 \& Occu6 are insignificant. Further, returns to Occu2 \& Occu7 are higher for females as compared to those engaged in the Occu3, the reference category. Age1 has been used as a reference category in the estimated earning functions. Males in the age groups 20-29, 30-30 and 40-49 earn more than those in the Age1 while females in these groups earn less. However, earnings of female in Age6 are higher as compared to those in the reference group but are significant in education dummies specification only as compared to male workers who earn less if compared with the reference category (Table 4).

Table 4: Results of OLS estimation for Males and Females

Dependent Variable: In_y

\begin{tabular}{l|c|c|c|c}
\hline \multirow{2}{*}{ Variables } & \multicolumn{2}{|c|}{ Males } & \multicolumn{2}{c}{ Females } \\
\cline { 2 - 5 } S & Edu Years & Edu Levels & Edu Years & Edu Levels \\
edu1 & $0.086^{* * *}$ & & $0.207^{* * *}$ & \\
edu2 & & -0.022 & & 0.074 \\
edu3 & & $0.107^{* *}$ & & 0.489 \\
edu4 & & $0.281^{* * *}$ & & $0.909^{* *}$ \\
edu5 & & $0.460^{* * *}$ & & $1.054^{* * *}$ \\
lit1 & & $0.893^{* * *}$ & & $1.855^{* * *}$ \\
lit2 & $-0.261^{* * *}$ & $0.184^{* * *}$ & $-0.856^{* * *}$ & 0.085 \\
Exp & -0.035 & -0.025 & $-0.183^{* *}$ & $-0.175^{*}$ \\
exp_sq & $0.057^{* * *}$ & $0.053^{* * *}$ & $0.092^{* * *}$ & $0.073^{* * *}$ \\
ind1 & $-0.001^{* * *}$ & $-0.001^{* * *}$ & $-0.001^{* * *}$ & $-0.001^{* * *}$ \\
ind2 & $0.097^{* *}$ & $0.070^{*}$ & -0.093 & -0.037 \\
ind3 & $0.157^{* * *}$ & $0.147^{* * *}$ & -0.181 & -0.137 \\
ind4 & $0.325^{* * *}$ & $0.305^{* * *}$ & $-0.734^{* *}$ & $-0.695^{*}$ \\
ind6 & $0.203^{* * *}$ & $0.188^{* * *}$ & 0.13 & 0.253 \\
ind7 & $0.225^{* * *}$ & $0.212^{* * *}$ & $0.550^{* *}$ & $0.627^{* *}$ \\
occu1 & $0.116^{* * *}$ & $0.107^{* * *}$ & -0.159 & -0.113 \\
occu2 & $0.432^{* * *}$ & $0.405^{* * *}$ & 0.13 & $0.234^{* *}$ \\
occu4 & $0.252^{* * *}$ & $0.239^{* * *}$ & $0.173^{*}$ & $0.249^{* *}$ \\
occu5 & 0.012 & 0.041 & -0.228 & -0.261 \\
& $-0.094^{* * *}$ & $-0.071^{* * *}$ & -0.095 & -0.115
\end{tabular}




\begin{tabular}{|c|c|c|c|c|}
\hline occu6 & -0.039 & -0.006 & 0.256 & 0.213 \\
\hline occu7 & $-0.126 * * *$ & $-0.115 * * *$ & $0.247 * * *$ & $0.216 * * *$ \\
\hline age1 & - & - & - & - \\
\hline age2 & $0.122 * * *$ & $0.165^{* * *}$ & $-0.314 * * *$ & -0.176 \\
\hline age3 & $0.102 * *$ & $0.183 * * *$ & $-0.527 * * *$ & -0.216 \\
\hline age4 & 0.064 & $0.182 * * *$ & -0.376 & 0.095 \\
\hline age5 & -0.034 & 0.126 & -0.278 & 0.356 \\
\hline age6 & $-0.322 * * *$ & -0.1 & 0.223 & $0.975 * *$ \\
\hline Cons & $7.605^{* * *}$ & $7.647 * * *$ & $6.793 * * *$ & $6.936 * * *$ \\
\hline F Statistics & 380.7 & 328.08 & 56.71 & 42.53 \\
\hline Adj. $R^{2}$ & 0.55 & 0.555 & 0.548 & 0.516 \\
\hline $\mathrm{N}$ & 6828 & 6828 & 1014 & 1014 \\
\hline
\end{tabular}

$* * *$ significant at $1 \%$ level; ${ }^{* *}$ significant at $5 \%$ level; ${ }^{*}$ significant at $10 \%$ level

Source: Authors Calculations

OLS estimates which are based on the mean of the conditional distribution of dependent variable in the regression analysis and are subject to be affected by the outliers present in a cross-sectional data. This is evident from the fact that mean earnings of both male and female workers having tertiary education were more than double of respective averages in the sample. Due to wide variation in the earnings of individuals, QR has been estimated for males and females and results are presented in Appendix (1) and (2) respectively. The results of QR at $5^{\text {th }}, 25^{\text {th }}, 50^{\text {th }}, 75^{\text {th }}$ and $95^{\text {th }}$ quantiles for male urban employees are presented in the appendix 1. The return to additional year of schooling at $5^{\text {th }}$ quantile for male workers stands at $9.1 \%$ and tends to decline from lower to upper quantiles and is $8.1 \%$ at $95^{\text {th }}$ quantile (Appendix 1 ). The lower levels of education like edu1 and edu2 are insignificant for urban male wage-earners at all levels of quantiles except $25^{\text {th }}$ and $75^{\text {th }}$ quantiles. However, higher levels of education like edu3, edu4 and edu5, have been emerged as significant and positive determinants of income for urban male employees at all levels of income distribution (Appendix 1).

Moreover, the returns to additional year of experience for male employees in urban areas decline along with movement from bottom towards top of the distribution and stands at $7.9 \%$ and $3.6 \%$ at $5^{\text {th }}$ and $95^{\text {th }}$ quantiles in education years specifications. The concavity of the earning functions is also confirmed for male wage earners and is evident from the negative and highly significant values of the squared term of experience. All levels of industry have been emerged as significant determinant of income for male urban employees except for Ind1 at all quantiles. Occu1, Occu2 and Occu7 are significant determinant of income at all parts of the distribution against Occu4 and Occu6 which are insignificant. Further, males in the younger age groups in urban areas earn significantly more than older workers in Age6 (Appendix 1).

The earning functions for females estimated through $Q R$ at various levels of quantiles are presented in appendix 2. The average return to additional year of schooling for female workers in urban areas at $5^{\text {th }}, 25^{\text {th }}$, $50^{\text {th }}, 75^{\text {th }}$, and $95^{\text {th }}$ quantiles stands at $21.9 \%, 21.2 \%, 20.2 \%, 20.1 \%$ and $19.3 \%$ respectively (Appendix 2 ). Edu1 and edu2 are not significant factors of income at all estimated quantiles for female workers. But edu3 is significant factor of income for female employees belonging to middle and higher middle income groups. Likewise, edu4 is significant for females at $5^{\text {th }}, 50^{\text {th }}$, and $75^{\text {th }}$ quantiles (Appendix 2). However, edu5 has been emerged as significant factor for determination of income of female employees irrespective of their position in the income distribution. Experience has also been emerged as positive and significant determinant for females at all levels of income distribution except for those in the $95^{\text {th }}$ quantile under education at levels specification (Appendix 2). Earning functions for females have also been found to be non-linear as is evident from negative and significant values of exp_sq term at all levels of estimated quantiles. This is consistent with finding of Aslam (2005), who found more convex education-earning profiles for women than men. Ind3 and Ind6 have been found as significant factor for income determination of female workers only in the lower-middle, middle, and upper-middle part of the income distribution. According to Blau and Kahn (2007), these gender differences in industry are also responsible for creating gender differences in income. Occu1 is significant for female workers in education levels specification at $25^{\text {th }}, 50^{\text {th }}$ and 75 quantiles whereas Occu 2 is significant at $1 \%$ and $10 \%$ levels at $25^{\text {th }}$ and $95^{\text {th }}$ quantiles respectively. While Occu4 is insignificant at all quantile, the Occu6 and Occu5 are 
significant at $5^{\text {th }}\left(5 \%\right.$ level) and $95^{\text {th }}$ (10\% level) quantiles respectively (Appendix 2$)$. The Occu 7 is mainly significant factor for the determination of income of female workers falling in the lower and lower-middle parts of the income distribution (Appendix 2). The gender differences in occupation account for considerable portion of gender earnings gap (Blau \& Kahn, 2007). Moreover, age used in different groups has been found as significant determinant of income for females belonging to lower-middle and middle class only. Age has not been found as significant factor of income determination for females in the $75^{\text {th }}$ and $95^{\text {th }}$ quantiles (Appendix 2).

The private return to different levels of education for both male and female workers belonging to urban Pakistan have been calculated by using equations (6) through (10) and are presented in the figure 4 . The private incremental returns to education for females are higher as compared to males in OLS estimates as well as in various quantiles at all levels of education except for $50^{\text {th }}, 75^{\text {th }}$ and $95^{\text {th }}$ quantiles at higher secondary levels (Figure 4). For female workers, lower levels of education yield higher returns at bottom part of the income distribution while higher level of education give more returns at uppor part of the income distribution. For example, average returns to an additional year of schooling for female workers having primary and secondary education at $5^{\text {th }}$ quantile were $14 \%$ and $42 \%$ as compared to $1 \%$ and $10 \%$ for their male counterparts respectively (Figure 4).

\section{Figure 4: Returns to Education by Level of Education and Sex in Urban Pakistan}
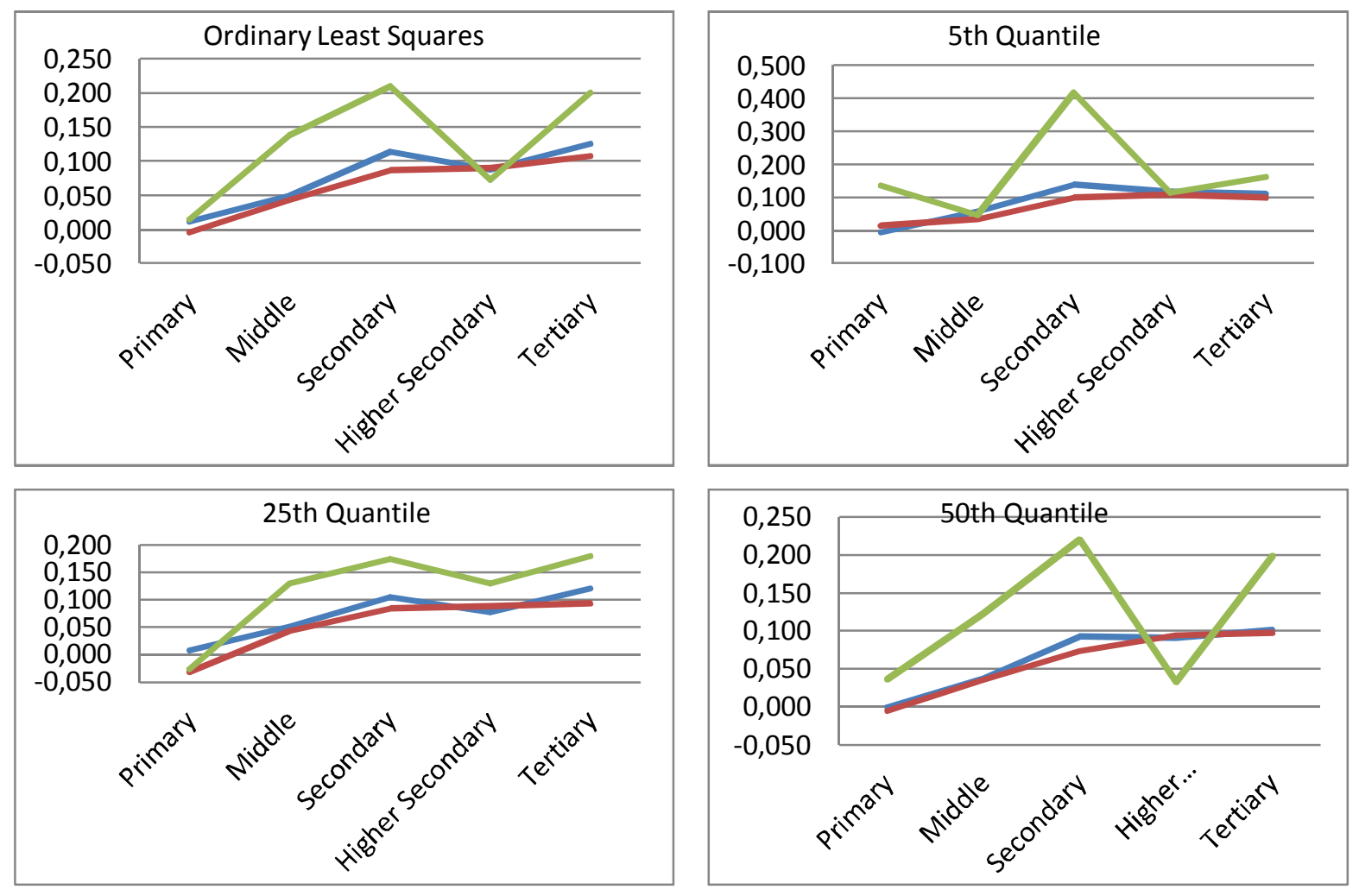

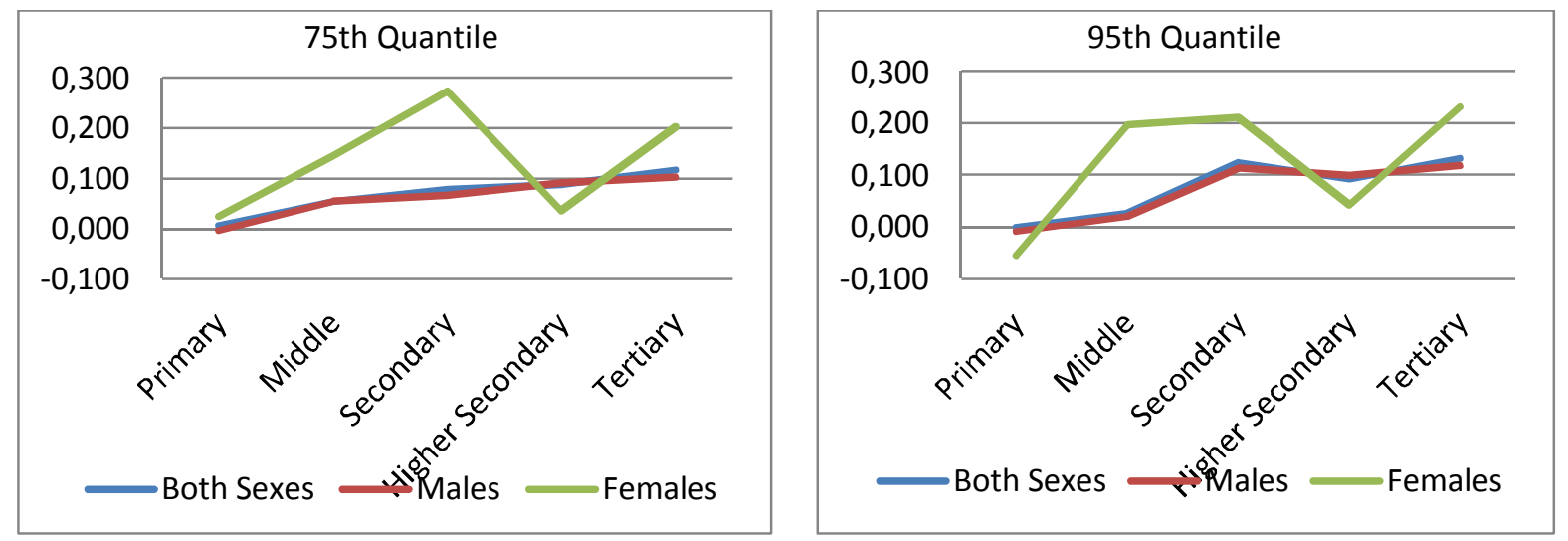

Another important objective of the current study is to decompose the gender income gap using Blinder-Oaxaca decomposition method whose results are presented in table 5 . The log income difference between male and female workers in urban areas of Pakistan stands at 0.666 (Table 5). This gap has been decomposed into various constituents such as education, literacy, experience, industry as well occupations of employment and age of individuals. According to the results about $43 \%$ of the income gap between male and female employees arises due to difference in education as compared to $8.1 \%$ from the literacy rate but former being the positive and later is negative. The gaps in wages by gender exist due to difference in experience (Polachek \& Xiang, 2014; Taniguchi \& Tuwo, 2014). Women usually tend to have shorter experience of work due to exit and entry into the labor market following family reasons (Blau \& Kahn, 2007; Pastore, et al., 2013; Polachek \& Xiang, 2014; Taniguchi \& Tuwo, 2014). Our decomposition suggests that differences in labor market experience constitute about $2 \%$ of income differences between male and female workers. Industry of employment has been found as positive contributor towards income gap between male and female paid employees in urban areas of Pakistan and its share stands at about $17 \%$. Income gaps between male and female workers arising due to difference in occupation and age stand at $-10.4 \%$ and $13.2 \%$ respectively (Table 5 ). In aggregates terms, our decomposition analysis is able to explain about 0.62 (93\%) of total log income difference of 0.666 between males and females.

Table 5: Decomposition of Gender Income Gap

\begin{tabular}{l|c}
\hline Variables & \multicolumn{2}{|c}{$\begin{array}{c}\text { Attributable to differences } \\
\text { in characteristics }\end{array}$} \\
\hline log income difference & 0.666 \\
Education: & -42.519 \\
Edu1 & -0.008 \\
Edu2 & -0.018 \\
Edu3 & -0.041 \\
Edu4 & -0.062 \\
Edu5 & -0.437 \\
Literacy: & 8.109 \\
Lit1 & 0.080 \\
Lit2 & 0.136 \\
Experience: & 1.768 \\
Experience & -0.298 \\
Exp_sq & 0.345 \\
Industry & 16.653 \\
Ind1 & 0.003 \\
Ind2 & 0.042 \\
Ind3 & 0.011 \\
Ind4 & 0.026
\end{tabular}




\begin{tabular}{l|r} 
Ind5 & 0.011 \\
Ind7 & 0.128 \\
Occupation: & -10.419 \\
Occu1 & -0.035 \\
Occu2 & -0.013 \\
Occu4 & 0.001 \\
Occu5 & 0.006 \\
Occu6 & -0.002 \\
Occu7 & -0.097 \\
Age: & 13.201 \\
Age1 & 0.000 \\
Age2 & 0.114 \\
Age3 & 0.091 \\
Age4 & 0.018 \\
Age5 & -0.021 \\
Age6 & -0.025 \\
Total Explained & 0.617 \\
Total Explained (\%) & 92.668 \\
\hline
\end{tabular}

Source: Author's Calculations

\section{CONCLUSION}

The objective of this paper was to analyze the gender earning gaps existing in urban areas of Pakistan using data from a household survey known as Household Integrated Economic Survey (HIES). The earnings functions have been estimated separately for males and females using Ordinary Least Squares (OLS) as well as quantile regressions including education, literacy, experience, employment related variables such type of industry and occupation and age as explanatory variables. The earnings gap between males and females has also been analyzed using the Blinder-Oaxaca decomposition method. Results suggest higher mean years of schooling and experience as well as monetary earnings for males as compared to females. However, higher incremental returns to investment in human capital for females have been observed at all levels of education in both OLS and quantiles regression performed at $5^{\text {th }}, 25^{\text {th }}, 50^{\text {th }}, 75^{\text {th }}$, and $95^{\text {th }}$ quantiles. Further, higher returns to schooling have also been noted in bottom part of the income distribution i.e. $5^{\text {th }} \& 25^{\text {th }}$ quantiles both for male and female workers as compared to those present in the top of the distribution i.e. $75^{\text {th }} \& 95^{\text {th }}$ quantiles at all educational levels. Further, according to decomposition analysis conducted through Blinder-Oaxaca method, education, industry of employment and occupations has been emerged as the main determinants of income gap between male and female workers in urban Pakistan. Private rates of return estimated through OLS and quantile regressions are used to explain the behavior of individuals in seeking different levels of education and are a useful indicator for the assessment of level of productivity of an individual. Policy makers can use the evidence provided through these estimates to design the programs aiming at the promotion of investment in education in order to reduce the gender differences in income. The findings also suggest offering incentive to low-income families for making investment in human capital through education. 


\section{REFERENCES}

Afzal, M., Malik, M. E., Begum, I., Sarwar, K., \& Fatima, H. (2011). Relationship among Education, Poverty and Economic Growth in Pakistan: An Econometric Analysis. Journal of Elementary Education, Vol.22, No. 1 pp.23-45.

Ali, L. (2007). Returns to Education in Pakistan. Master of Philosophy in Economics Dissertation, International Islamic University (IIU), Islamabad, Pakistan, Islamabad.

Ali, L., \& Akhtar, N. (2014). An Analysis of the Gender Earning Differentials in Pakistan. Research Journal of Applied Sciences, Engineering and Technology. Volume 7, Issue 13, April 2014

Ashraf, B. (2001). An Intertemporal Comparison of the Gender-Wage Gap in Pakistan and a Comparison with Other Countries. Doctor of Philosophy Dissertation, University of Karachi, Karachi.

Ashraf, J., \& Ashraf, B. (1993). An Analysis of the Male-Female Earnings Differentials in Pakistan. The Pakistan Development Review 32 : 4 Part-II (Winter 1993) pp. 895-904.

Aslam, M. (2005). Rates of Return to Education by Gender in Pakistan. Global Poverty Research Group, GPRG -WPS-064.

Bauer, J., Feng, W., Riley, N. E., \& Xiaohua, Z. (1992). Gender Inequality in Urban China: Education and Employment. Modem China, Vol. 18, No. 3. (Jul., 1992), pp. 333-370.

Bertocchi, G., \& Bozzano, M. (2014). Family Structure and the Education Gender Gap: Evidence from Italian Provinces. DEMB Working Paper Series N. 36, July 2014.

Blau, F. D., \& Kahn, L. M. (2007). The Gender Pay Gap: Have Women Gone as Far as They Can? Academy of Management Perspectives, 2007, pp 7-23.

Boraas, S., \& Rodgers, W. M. (2003). How does gender play a role in the earnings gap? an update. Monthly Labor Review, March 2003, pp 9-15.

Brown, P. (2003). The Opportunity Trap: Education and Employment in a global economy. European Educational Research Journal, Volume 2, Number 1, 2003.

Cade, B. S., \& Noon, B. R. (2003). A Gentle Introduction to Quantile Regression for Ecologists. Front Ecol Environ 2003; 1(8): 412-420.

Chzhen, Y., \& Mumford, K. (2010). Gender Gaps across The Earnings Distribution For Full-Time Employees in Britain: Allowing For Sample Selection. Online article accessed on 05-11-2014 from the link:

Coad, A., \& Rao, R. (2007). Innovation and Firm Growth in High-Tech Sectors: A Quantile Regression Approach. LEM Working Paper Series, No. $2006 / 18$.

Dougherty, S., \& Herd, R. (2008). Improving Human Capital Formation in India. OECD Economics Department Working Papers, No. 625, , OECD Publishing. Avaiable on the link: http://dx.doi.org/10.1787/241005853765. doi: 10.1787/241005853765

Emran, M. S., \& Shilpi, F. (2014). Gender, Geography and Generations: Intergenerational Educational Mobility in Post-reform India. MPRA Paper No. 58316, September 2014 URL: http://mpra.ub.uni-muenchen.de/58316/. Accessed on 23-11-2014

Fattouh, B., Scaramozzino, P., \& Harris, L. (2001). Capital Structure in South Korea: A Quantile Regression Approach. Centre for Financial and Management Studies at SOAS, the University of London, Discussion Paper August 2001. Accessed from the link http://www.cefims.ac.uk/documents/research-12.pdf on 31-12-2014

Finance, M. o. (2014). Pakistan Economic Survey, 2013-14. Finance Division, Government of Pakistan, Chapter 10, Education, pp 147-165

Gornick, J. C., \& Jacobs, J. A. (1998). Gender, the Welfare State, and Public Employment: A Comparative Study of

Seven Industrialized Countries. American Sociological Review, Vol. 63, No. 5 (Oct., 1998), 688-710.

Grajek, M. (2001). Gender Pay Gap in Poland. WZB Discussion Paper, No. FS IV 01-13, URL: http://hdl.handle.net/10419/50954.

Guichard, S., \& Larre, B. (2006). Enhancing Portugal's Human Capital. OECD Economics Department Working Papers, No. 505, , OECD Publishing. Available on the link: http://dx.doi.org/10.1787/871641300584. doi: 10.1787/871641300584

Harkness, S. (1996). The Gender Earnings Gap: Evidence from the UK. Fiscal Studies (1996) Vol. 17, No. 2, pp. 1-36.

Jehan, Q. (2000). Role of Women in Economic Development of Pakistan. Doctor of Philosophy Dissertation, University of Balochistan, Quetta, Pakistan.

Jung, S. (2014). "The Gender Wage Gap and Sample Selection via Risk Attitudes". Thema Working Paper No. 2014-25, Université de Cergy Pontoise, France, October, 2014.

Kingdon, G. G. (2001). The gender gap in educational attainment in India: How much can be explained? Department of Economics, University of Oxford, Oxford OX1 3UQ, August, 2001.

Koenker, R., \& Hallock, K. F. (2001). Quantile Regression. Journal of Economic Perspectives, 15(4), 143-156. 
Malhotra, A., Pande, R., \& Grown, C. (2003). Impact of Investments in Female Education on Gender Equality International Center for Research on Women, Working Paper, August 2003

Martins, P. S., \& Pereira, P. T. (2004). Does Education Reduce Wage Inequality? Quantile Regression Evidence from 16 Countries. Labour Economics 11 (2004) 355-371. doi: 10.1016/j.labeco.2003.05.003

Melly, B. (2002). Public-Private Sector Wage Differentials in Germany: Evidence From Quantile Regression. An online article accessed from the link file:///C:/Users/Dell1/Downloads/2002.pdf on 31-12-2014.

MOF. (2014). Pakistan Economic Survey 2013-14. Islamabad: Ministry of Finance, Government of Pakistan.

Montenegro, C. E., \& Patrinos, H. A. (2014). Comparable Estimates of Returns to Schooling Around the World. World Bank Education Global Practice Group, Policy Research Working Paper 7020, September 2014.

Nasir, Z. M. (1998). Determinants of Personal Earnings in Pakistan: Findings from the Labour Force Survey 1993-94. The Pakistan Development Review 37 : 3 (Autumn 1998) pp. 251-274.

Nasir, Z. M. (2005). An Analysis of Occupational Choice in Pakistan: A Multinomial Approach. The Pakistan Development Review $44: 1$ (Spring 2005) pp. 57-79.

Pastore, F., Sattar, S., \& Tiongson, E. R. (2013). Gender Differences in Earnings and Labor Supply in Early Career: Evidence from Kosovo's School-to-Work Transition Survey. IZA Journal of Labor \& Development, 2013.

PBS. (2011). Household Integrated Economic Survey 2010-11. Pakistan Bureau of Statistics, Statistics Division, Government of Pakistan, Islamabad. Accessed from the link: http://www.pbs.gov.pk/sites/default/files/ps/m/publications/hies10_11/complete_report.pdf on 31-122014.

PBS. (2014a). Pakistan Employment Trends 2013. Islamabad: Pakistan Bureau of Statistics (PBS), Statistics Division, Government of Pakistan.

PBS. (2014b). Pakistan Social \& Living Standards Measurement Survey (PSLM). Pakistan Bureau of Statistics (PBS), Statistics Division, Government of Pakistan, Islamabad. Accessed from the link: http://www.pbs.gov.pk/content/pakistan-social-and-living-standardsmeasurement accessed on 31-12-2014.

Pham, T.-H., \& Reilly, B. (2007). The Gender Pay Gap in Vietnam, 1993-2002: A Quantile Regression Approach. MPRA Paper No. 6475, posted 29. December 2007 07:09 UTC. Online at http://mpra.ub.uni-muenchen.de/6475/.

Polachek, S. W., \& Xiang, J. (2014). The Gender Pay Gap Across Countries: A Human Capital Approach. IZA DP No. 8603, October 2014.

Psacharopoulos, G. (1985). Returns to Education: A Further International Update and Implications. The Journal of Human Resources, Volume XX, No. 4, pp 583-604.

Qureshi, M. G. (2012). The Gender Differences in School Enrolment and Returns to Education in Pakistan. Pakistan Institute of Development Economics, Islamabad, PIDE Working Papers 2012: 84.

Rice, P. (1999). Gender Earnings Differentials: The European Experience. The World Bank, Policy Research Report on Gender and Development Working Paper Series No.8.

Sarwar, F., Fakher, A., Ali, S., \& Mudassar, K. (2013). Human Capital, Population and Economic Growth: A Cointegration Approach. Universal Journal of Management and Social Sciences Vol. 3, No.10; October 2013.

Siddiqui, R. (2007). Modeling Gender Dimensions of the Impact of Economic Reforms in Pakistan. Poverty and Economic Policy Research Network, MPIA Working Paper 2007:13.

Siddiqui, R., \& Siddiqui, R. (1998). A Decomposition of Male-Female Earnings Differentials. The Pakistan Development Review $37: 4$ Part II (Winter 1998) pp. 37:4, 885-898.

Son, H. H. (2010). Human Capital Development. Asian Development Bank (ADB) Economics Working Paper Series No. 225, Manila, Philippines., URL: www.adb.org/economics.

Su, B., \& Heshmati, A. (2013). Analysis of the Determinants of Income and Income Gap between Urban and Rural China. IZA Discussion Paper Series, Discussion Paper No. 7162 January 2013.

Taniguchi, K., \& Tuwo, A. (2014). New Evidence on the Gender Wage Gap in Indonesia. Asian Development Bank (ADB) Economics Working Paper Series, No. 404, 2014.

UN. (2016). An online content accessed from the link http://www.un.org/sustainabledevelopment/gender-equality/ on 17-05-2016

UN. (2014). The Millennium Development Goals Report 2014. United Nations, New York, 2014.

UNDP (2016). An online content accessed from the link http://www.pk.undp.org/content/pakistan/en/home/post-2015/sdg-overview.html on 17-05-2016

UNDP. (2015). United Nations Development Programme (UNDP) Pakistan Annual Report, 2015. 
UNDP. (2014a). Fast Facts: Gender Equality and UNDP. United Nations Development Programme, New York, February, 2014.

UNDP. (2014b). Gender Equality Strategy 2014-17. United Nations Development Programme, New York, 2014.

Vassil, K., Eamets, R., \& Mõtsmees, P. (2014). Socio-demographic Model of Gender Gap in Expected and Actual Wages in Estonia. IZA DP No. 8604, October 2014.

Weichselbaumer, D., \& Winter-Ebmer, R. (2003). A Meta-Analysis of the International Gender Wage Gap, . IZA Discussion paper series, No. 906 URL: http://hdl.handle.net/10419/20143.

Willis, R. J. (1986). Wage Determinants: A Survey and Reinterpretation of Human Capital Earnings Functions. In O. Ashenfelter \& R. Layard (Eds.), Handbook of Labor Economics (Vol. L, pp. 525-602): Elsevier Science Publishers BV.

Wu, Y., \& Liu, Y. (2009). Variable Selection in Quantile Regression. Statistica Sinica 19 (2009), pp. 801-817.

Yamauchi, F. (2010). Human Capital Formation: History, Expectations, and Challenges in South Africa. International Food Policy Research Institute, Washington, D.C. U.S.A. URL: www.ifpri.org DOI: 10.2499/9780896291805.

Yu, K., Lu, Z., \& Stander, J. (2003). Quantile Regression: Applications and Current Research Areas. The Statistician (2003) 52, Part 3, pp. 331350. 


\section{Appendix 1: Results of Quantile Regression for Males}

\begin{tabular}{|c|c|c|c|c|c|c|c|c|c|c|}
\hline \multirow[b]{2}{*}{$\begin{array}{c}\text { Variable } \\
\text { s }\end{array}$} & \multicolumn{2}{|c|}{ Q5 } & \multicolumn{2}{|c|}{ Q25 } & \multicolumn{2}{|c|}{ Q50 } & \multicolumn{2}{|c|}{ Q75 } & \multicolumn{2}{|c|}{ Q95 } \\
\hline & $\begin{array}{l}\text { Edu } \\
\text { Years }\end{array}$ & $\begin{array}{l}\text { Edu } \\
\text { Levels }\end{array}$ & $\begin{array}{l}\text { Edu } \\
\text { Years }\end{array}$ & $\begin{array}{l}\text { Edu } \\
\text { Levels }\end{array}$ & $\begin{array}{l}\text { Edu } \\
\text { Years }\end{array}$ & $\begin{array}{l}\text { Edu } \\
\text { Levels }\end{array}$ & $\begin{array}{l}\text { Edu } \\
\text { Years }\end{array}$ & $\begin{array}{l}\text { Edu } \\
\text { Levels }\end{array}$ & $\begin{array}{l}\text { Edu } \\
\text { Years }\end{array}$ & $\begin{array}{l}\text { Edu } \\
\text { Levels }\end{array}$ \\
\hline$S$ & $.091^{* * *}$ & & $\begin{array}{l}.0797^{* *} \\
*\end{array}$ & & $.080 * * *$ & & $.076 * * *$ & & $.081 * * *$ & \\
\hline edu1 & & 0.072 & & $-.154^{* *}$ & & -0.024 & & -0.019 & & -0.043 \\
\hline edu2 & & 0.172 & & -0.021 & & 0.084 & & $.146 * *$ & & 0.021 \\
\hline edu3 & & $.371^{* *}$ & & $.149 * *$ & & $.231 * * *$ & & $.279 * * *$ & & $.248 * * *$ \\
\hline edu4 & & $.589 * * *$ & & $.327 * * *$ & & $.420 * * *$ & & $.460 * * *$ & & $.446 * * *$ \\
\hline edu5 & & $.984 * * *$ & & $.699 * * *$ & & $.809 * * *$ & & $.872 * * *$ & & $.921 * * *$ \\
\hline lit1 & $\begin{array}{l}- \\
.297 * * *\end{array}$ & 0.088 & $-.256 * * *$ & $.281^{* * *}$ & $\begin{array}{l}- \\
.239 * * *\end{array}$ & $.199 * * *$ & $.221 * * *$ & $.162 * * *$ & $.194 * * *$ & $.221 * * *$ \\
\hline lit2 & -0.026 & 0.022 & 0.000 & 0.013 & -0.023 & -0.032 & -.048* & -0.039 & -0.077 & $-.100 * *$ \\
\hline Exp & $.079 * * *$ & $.072 * * *$ & $.061^{* * *}$ & $.061^{* * *}$ & $.052 * * *$ & $.050 * * *$ & $.043^{* * *}$ & $.040 * * *$ & $.036 * * *$ & $.033^{* * *}$ \\
\hline exp_sq & $.001 * * *$ & $.001 * * *$ & $-.001 * * *$ & $.001 * * *$ & $.001 * * *$ & $.001 * * *$ & $.000 * * *$ & $.000 * * *$ & $.000 * * *$ & $.000 * * *$ \\
\hline ind 1 & 0.174 & 0.136 & 0.087 & 0.063 & 0.064 & 0.037 & 0.074 & $.099 * *$ & 0.013 & 0.017 \\
\hline ind 2 & $.201 * * *$ & $.241 * * *$ & $.186 * * *$ & $.173 * * *$ & $.156^{* * *}$ & $.144 * * *$ & $.102 * * *$ & $.104 * * *$ & $.089 *$ & $.068^{*}$ \\
\hline ind 3 & $.421 * * *$ & $.398 * * *$ & $.409 * * *$ & $.366 * * *$ & $.386 * * *$ & $.337^{* * *}$ & $.280 * * *$ & $.309 * * *$ & $.179 *$ & $.213^{* * *}$ \\
\hline ind 4 & $.201 * * *$ & $.235^{* * *}$ & $.186^{* * *}$ & $.186^{* * *}$ & $.201 * * *$ & $.180 * * *$ & $.160 * * *$ & $.162^{* * *}$ & $.165^{* * *}$ & $\begin{array}{l}0.134^{* *} \\
*\end{array}$ \\
\hline ind 6 & $.253^{* * *}$ & $.290 * * *$ & $.197^{* * *}$ & $.203^{* * *}$ & $.247^{* * *}$ & $.244 * * *$ & $.210 * * *$ & $.214 * * *$ & $.119 * *$ & $.128 * * *$ \\
\hline ind 7 & 0.063 & 0.093 & $.135^{* * *}$ & $.134 * * *$ & $.167^{* * *}$ & $.161^{* * *}$ & $.143^{* * *}$ & $.152^{* * *}$ & $.101^{* * *}$ & $.063^{* *}$ \\
\hline occu1 & $.240 * * *$ & $0.131^{*}$ & $.348 * * *$ & $.306 * * *$ & $.435^{* * *}$ & $.443 * * *$ & $.575 * * *$ & $.510 * * *$ & $.684^{* * *}$ & $.601 * * *$ \\
\hline occu 2 & 0.132 & 0.079 & $.278 * * *$ & $.216^{* * *}$ & $.255^{* * *}$ & $.262 * * *$ & $.263^{* * *}$ & $.257^{* * *}$ & $.295^{* * *}$ & $.299 * * *$ \\
\hline occu4 & 0.067 & 0.229 & 0.069 & 0.110 & 0.013 & 0.066 & 0.006 & 0.024 & -0.041 & -0.039 \\
\hline occu5 & $\begin{array}{l}- \\
.314 * * *\end{array}$ & $.332 * * *$ & $-.100 * * *$ & $\begin{array}{l}- \\
.088 * * *\end{array}$ & $-.049 * *$ & -0.020 & 0.007 & 0.029 & -0.003 & 0.047 \\
\hline occu6 & -0.085 & -0.042 & -0.013 & -0.012 & -0.040 & -0.007 & -0.004 & 0.020 & -0.074 & -0.023 \\
\hline occu7 & $-.118^{*}$ & $-.134 * *$ & $-.134^{* * *}$ & $.127^{* * *}$ & $.131^{* * *}$ & $.115^{* * *}$ & $-133^{-} * *$ & $.115^{* * *}$ & $.213^{-} * *$ & $\begin{array}{l}- \\
.169 * * *\end{array}$ \\
\hline age1 & 0.234 & 0.266 & $.271 * *$ & 0.135 & $.240 * *$ & 0.059 & $.223^{*}$ & 0.123 & 0.249 & 0.011 \\
\hline age2 & $.660 * *$ & $.709 * * *$ & $.446^{* * *}$ & $.313^{* * *}$ & $.314 * * *$ & $.173^{*}$ & $.275^{* * *}$ & $.195^{*}$ & 0.246 & 0.047 \\
\hline age3 & $.593 * *$ & $.698 * * *$ & $.418 * * *$ & $.297 * * *$ & $.278 * * *$ & $.164^{* *}$ & $.313^{* * *}$ & $.239 * * *$ & $.303^{* *}$ & 0.158 \\
\hline age4 & $.624 * * *$ & $.748 * * *$ & $.382 * * *$ & $.270 * * *$ & $.266 * * *$ & $.169 * * *$ & $.295^{* * *}$ & $.256 * * *$ & $.275^{* *}$ & $.165^{*}$ \\
\hline age5 & $.416 * * *$ & $.529 * * *$ & $.268 * * *$ & $.197 * * *$ & $.193 * * *$ & $.149 * * *$ & $.272 * * *$ & $.221 * * *$ & $.238 * * *$ & $.190 * *$ \\
\hline age6 & 0.000 & 0.000 & 0.000 & 0.000 & 0.000 & 0.000 & 0.000 & 0.000 & 0.000 & 0.000 \\
\hline Cons & $\begin{array}{l}6.126^{* *} \\
*\end{array}$ & 6.135 & $\begin{array}{l}6.988 * * \\
*\end{array}$ & $\begin{array}{l}7.172^{* *} \\
*\end{array}$ & $\begin{array}{l}7.494^{* *} \\
*\end{array}$ & $\begin{array}{l}7.699 * * \\
*\end{array}$ & $\begin{array}{l}7.922 * * \\
*\end{array}$ & $\begin{array}{l}8.029 * * \\
*\end{array}$ & $\begin{array}{l}8.431 * * \\
*\end{array}$ & $\begin{array}{l}8.717^{* *} \\
*\end{array}$ \\
\hline $\begin{array}{l}\text { Pseudo } \\
\text { R2 }\end{array}$ & 0.287 & 0.288 & 0.294 & 0.296 & 0.337 & 0.342 & 0.396 & 0.402 & 0.451 & 0.462 \\
\hline$N$ & 6828.00 & 6828.00 & 6828.00 & 6828.00 & 6828.00 & 6828.00 & 6828.00 & 6828.00 & 6828.00 & 6828.00 \\
\hline $\mathbf{N}$ & 0 & 0 & 0 & 0 & 0 & 0 & 0 & 0 & 0 & 0 \\
\hline
\end{tabular}

***significant at $1 \%$ level; ${ }^{* *}$ significant at $5 \%$ level; ${ }^{*}$ significant at $10 \%$ level

Source: Authors Calculations 
Appendix 2: Result of Quantile Regression for Females

Dependent Variable: In_y

\begin{tabular}{|c|c|c|c|c|c|c|c|c|c|c|}
\hline \multirow[b]{2}{*}{ Variables } & \multicolumn{2}{|c|}{ Q5 } & \multicolumn{2}{|c|}{ Q25 } & \multicolumn{2}{|c|}{ Q50 } & \multicolumn{2}{|c|}{ Q75 } & \multicolumn{2}{|c|}{ Q95 } \\
\hline & $\begin{array}{l}\text { Edu } \\
\text { Years }\end{array}$ & $\begin{array}{l}\text { Edu } \\
\text { Levels }\end{array}$ & $\begin{array}{l}\text { Edu } \\
\text { Years }\end{array}$ & $\begin{array}{l}\text { Edu } \\
\text { Levels }\end{array}$ & $\begin{array}{l}\text { Edu } \\
\text { Years }\end{array}$ & $\begin{array}{l}\text { Edu } \\
\text { Levels }\end{array}$ & $\begin{array}{l}\text { Edu } \\
\text { Years }\end{array}$ & $\begin{array}{l}\text { Edu } \\
\text { Levels }\end{array}$ & $\begin{array}{l}\text { Edu } \\
\text { Years }\end{array}$ & $\begin{array}{l}\text { Edu } \\
\text { Levels }\end{array}$ \\
\hline $\begin{array}{l}\text { S } \\
\text { edu1 } \\
\text { edu2 } \\
\text { edu3 } \\
\text { edu4 } \\
\text { edu5 }\end{array}$ & $.219 * * *$ & $\begin{array}{l}0.685 \\
0.823 \\
1.657 \\
1.887^{*} \\
2.534^{* *}\end{array}$ & $.212^{* * *}$ & $\begin{array}{l}-0.131 \\
0.262 \\
0.612 \\
0.872 \\
1.595^{* *}\end{array}$ & $.202^{* * *}$ & $\begin{array}{l}0.183 \\
0.551 \\
.992^{* *} \\
1.059 * * \\
1.853^{* * *}\end{array}$ & $.201 * * *$ & $\begin{array}{l}0.124 \\
0.562 \\
1.109 * * \\
1.182 * * \\
1.994 * * *\end{array}$ & $.193^{* * *}$ & $\begin{array}{l}-0.268 \\
0.322 \\
0.743 \\
0.830 \\
1.755^{* *}\end{array}$ \\
\hline lit1 & $1.054^{* * *}$ & -0.5284 & $\begin{array}{l}- \\
1.046^{* * *}\end{array}$ & 0.318 & $-.726 * * *$ & 0.0335 & $-.793 * * *$ & 0.045 & $-.838 * * *$ & 0.117 \\
\hline lit2 & $-.471^{* *}$ & $-.470 * *$ & -0.053 & -0.098 & -0.121 & -0.0991 & -0.152 & -0.143 & $-.413 * * *$ & $-.363^{*}$ \\
\hline Exp & $.129 * * *$ & $.102 * *$ & $.107^{* * *}$ & $.104^{* * *}$ & $.104^{* * *}$ & $.089 * * *$ & $.0788 * * *$ & $.065^{* * *}$ & $.054 * * *$ & 0.0257 \\
\hline exp_sq & $-.002 * * *$ & $-.002 * * *$ & $-.002 * * *$ & $-.002 * * *$ & $-.002 * * *$ & $-.002 * * *$ & $-.001 * * *$ & $-.001 * * *$ & $-.001 * * *$ & 0.000 \\
\hline ind1 & $.965^{*}$ & 0.956 & -0.068 & -0.093 & -0.336 & -0.336 & $-.498 *$ & -0.334 & -0.067 & -0.098 \\
\hline ind 2 & 0.0373 & -0.217 & -0.14 & -0.085 & -0.231 & -0.181 & $-.369 *$ & -0.242 & 0.114 & 0.139 \\
\hline ind3 & 0.113 & 0.107 & -0.800 & -0.798 & $-.967 * *$ & $-.938 * *$ & $1.674 * * *$ & $-1.565^{* * *}$ & -0.379 & -0.343 \\
\hline ind 4 & 0.374 & 0.430 & -0.282 & -0.277 & 0.125 & 0.552 & 0.064 & 0.336 & 0.191 & 0.314 \\
\hline ind6 & -0.618 & -0.591 & $.821 * *$ & $.887^{* * *}$ & $.644^{* *}$ & $.556^{*}$ & 0.301 & 0.463 & -0.014 & 0.119 \\
\hline ind7 & 0.583 & 0.577 & -0.211 & -0.244 & -0.225 & -0.251 &.$-0.343^{*}$ & -0.242 & -0.242 & -0.223 \\
\hline occu1 & 0.198 & 0.204 & 0.200 & $.348 * * *$ & 0.133 & $.334 * * *$ & 0.092 & $.284 * *$ & 0.156 & 0.218 \\
\hline occu2 & 0.361 & 0.287 & $.353 * * *$ & $.399 * * *$ & 0.133 & $.372 * * *$ & 0.147 & 0.184 & $.310 *$ & $.383 *$ \\
\hline occu4 & -0.271 & -0.098 & -0.413 & -0.414 & 0.191 & 0.191 & -0.381 & -0.439 & -0.342 & -0.317 \\
\hline occu5 & 0.035 & 0.241 & -0.075 & -0.078 & -0.116 & -0.156 & -0.173 & -0.182 & $-.279 *$ & -0.332 \\
\hline occu6 & 0.954 & $1.591 * *$ & 0.619 & 0.594 & 0.301 & 0.267 & 0.023 & -0.034 & 0.188 & -0.073 \\
\hline occu7 & $.354 *$ & $.427^{*}$ & $.293^{* * *}$ & $.307^{* * *}$ & $.193^{*}$ & 0.141 & 0.108 & 0.078 & $.232 *$ & 0.182 \\
\hline age1 & -0.148 & -1.072 & -0.571 & -0.992 & -0.449 & $-1.274^{* *}$ & 0.178 & 0.145 & -0.041 & -0.722 \\
\hline age2 & -0.621 & -1.489 & -0.852 & $-1.255^{* *}$ & -0.72 & $1.342 * * *$ & -0.184 & -0.132 & -0.177 & -0.722 \\
\hline age3 & -1.103 & $-1.693 *$ & $-1.000 * *$ & $1.338^{* * *}$ & $-.937 * *$ & 1.419*** & -0.357 & -0.289 & -0.247 & -0.571 \\
\hline age4 & -0.937 & $-1.341 *$ & $-.814^{*}$ & $1.052^{* * *}$ & $-.814^{* *}$ & $\begin{array}{l}- \\
1.168 * * *\end{array}$ & -0.278 & -0.11 & -0.225 & -0.376 \\
\hline age5 & -0.954 &.$-1.066^{*}$ & $-.673^{* *}$ & $-.759 * *$ & $-.774 * * *$ & $-.818 * * *$ & -0.193 & -0.064 & -0.212 & -0.273 \\
\hline age6 & 0.000 & 0.000 & 0.000 & 0.000 & 0.000 & 0.000 & 0.000 & 0.000 & 0.000 & 0.000 \\
\hline Cons & $5.133 * * *$ & $6.220 * * *$ & $6.703^{* * *}$ & $7.243 * * *$ & $7.140 * * *$ & $8.099 * * *$ & $7.482 * * *$ & $7.516^{* * *}$ & $8.441 * * *$ & $9.361 * * *$ \\
\hline $\begin{array}{l}\text { Pseudo } \\
R^{2}\end{array}$ & 0.2304 & 0.2123 & 0.2728 & 0.2581 & 0.3684 & 0.3528 & 0.4294 & 0.4092 & 0.4103 & 0.3892 \\
\hline $\mathrm{N}$ & 1014 & 1014 & 1014 & 1014 & 1014 & 1014 & 1014 & 1014 & 1014 & 1014 \\
\hline
\end{tabular}

${ }^{* * *}$ significant at $1 \%$ level; ${ }^{* *}$ significant at $5 \%$ level; ${ }^{*}$ significant at $10 \%$ level

Source: Authors Calculations 